\title{
Concentration of Inorganic Elements Content in Benthic Seaweeds of Fernando de Noronha Archipelago by Synchrotron Radiation Total Reflection X-Ray Fluorescence Analysis (SRTXRF)
}

\author{
Leandro De Santis Ferreira, ${ }^{1}$ Rosana Peporine Lopes, ${ }^{2}$ \\ Mabel Norma Costas Ulbrich, ${ }^{2}$ Thais Guaratini, ${ }^{3}$ Pio Colepicolo, ${ }^{4}$ \\ Norberto Peporine Lopes, ${ }^{1}$ Ricardo Clapis Garla, ${ }^{5}$ Eurico Cabral Oliveira Filho, ${ }^{6}$ \\ Adrian Martin Pohlit, ${ }^{7}$ and Orghêda Luiza Araújo Domingues Zucchi' ${ }^{1}$ \\ ${ }^{1}$ Departamento de Física e Química, Faculdade de Ciências Farmacêuticas de Ribeirão Preto, Universidade de São Paulo, \\ 14040-903 Ribeirão Preto, SP, Brazil \\ ${ }^{2}$ Instituto de Geociências, Universidade de São Paulo, 05508-080 São Paulo, SP, Brazil \\ ${ }^{3}$ Lychnoflora Pesquisa e Desenvolvimento em Produtos Naturais LTDA, Incubadora SUPERA, Campus da USP, \\ 14040-900 Ribeirão Preto, SP, Brazil \\ ${ }^{4}$ Instituto de Química, Universidade de São Paulo, 05513-970 São Paulo, SP, Brazil \\ ${ }^{5}$ Departamento de Botânica, Ecologia e Zoologia, Centro de Biociências, Universidade Federal do Rio Grande do Norte, \\ 59072-970 Natal, RN, Brazil \\ ${ }^{6}$ Instituto de Biociências, Universidade de São Paulo, 05508-090 São Paulo, SP, Brazil \\ ${ }^{7}$ Coordenação de Pesquisa em Produtos Naturais, Instituto Nacional de Pesquisa da Amazônia, 69060-001 Manaus, AM, Brazil \\ Correspondence should be addressed to Leandro De Santis Ferreira, leansf@fcfrp.usp.br
}

Received 31 August 2011; Accepted 13 October 2011

Academic Editor: Ricardo Vessecchi

Copyright ( $) 2012$ Leandro De Santis Ferreira et al. This is an open access article distributed under the Creative Commons Attribution License, which permits unrestricted use, distribution, and reproduction in any medium, provided the original work is properly cited.

\begin{abstract}
SRTXRF was used to determine As, Ba, Br, Ca, Co, Cr, Cs, Cu, Dy, Fe, K, Mn, Mo, Ni, Pb, Rb, Sr, Ti, V, and Zn in eleven seaweed species commonly found in Fernando de Noronha: Caulerpa verticillata (J. Agardh) (Chlorophyta), Asparagopsis taxiformis (Delile), Dictyurus occidentalis (J. Agardh), Galaxaura rugosa (J. Ellis \& Solander) J. V. Lamouroux, G. obtusata (J. Ellis \& Solander) J. V. Lamouroux, G. marginata (J. Ellis \& Solander) J. V. Lamouroux (Rhodophyta), Dictyota cervicornis (Kützing), Dictyopteris justii (J. V. Lamouroux), Dictyopteris plagiogramma (Montagne) Vickers, Padina gymnospora (Kützing) Sonder, and a Sargassum sp. (Phaeophyta). Data obtained were compared to those from the analysis of other parts of the world seaweeds using different analytical techniques and were found to be in general agreement in terms of major and minor elemental components. Results provide baseline information about the absorption and accumulation of these elements by macroalgae in the area.
\end{abstract}

\section{Introduction}

In the South Atlantic Ocean is located Fernando de Noronha archipelago around $540 \mathrm{~km}$ of the northeastern Brazilian coast. This archipelago is composed by one large island and 20 small adjacent islets that represent a mountain chain top developed along an east-west fracture zone of the ocean floor and was built up by volcanic and subvolcanic essentially alkaline and subsaturated rocks [1].
The marine flora of Fernando de Noronha was first studied by Dickie [2]. Most of the investigations carried out since then were taxonomic studies [3-5]. Also, the families Dictyotaceae and Sargassaceae of brown algae, the green algae Caulerpa verticillata, and the red algae Galaxaura spp. are among the most abundant macroalgae on the rocky and reef shores of the archipelago $[5,6]$. Their predominance is probably related to the production of secondary metabolites that inhibit herbivore predation [7]. 
Seaweeds require various mineral ions for photosynthesis and growth. Also, it has long been established that marine and estuarine macroalgae accumulate metals to levels many times those found in the surrounding waters [7], and several algae have been used for monitoring concentrations of elements [8-12]. This study provides baseline information for further investigations of the absorption and accumulation of 20 elements by eleven macroalgae species commonly found in Fernando de Noronha archipelago. The concentrations of the elements in the seaweeds were determined using Synchrotron Radiation Total Reflection X-Ray Fluorescence Analysis (SRTXRF).

\section{Experimental}

2.1. Chemicals Reagents and Solutions. All the reagents were purchased from Merck (Darmstadt, HE, Germany) and Synth (Diadema, SP, Brazil). The multielementary solution was prepared using monoelementary solutions purchased from Acros Organics (Geel, ANT, Belgium and New Jersey, NJ, USA), and ultrapure (deionized) water was obtained using a deionizer from Microtec (Ribeirão Preto, SP, Brazil).

2.2. Sampling. Eleven species of seaweeds commonly found in Fernando de Noronha archipelago were studied: Caulerpa verticillata (Chlorophyta), Asparagopsis taxiformis, Dictyurus occidentalis, Galaxaura rugosa, G. obtusata, G. marginata (Rhodophyta), Dictyota cervicornis, Dictyopteris justii, Dictyopteris plagiogramma, Padina gymnospora, and a Sargassum sp. (Phaeophyta) Samples were collected in February and March, 2006 at Caieiras Beach $\left(3^{\circ} 50^{\prime} 18.8^{\prime \prime}\right.$ S, 32 $\left.23^{\prime} 57.3^{\prime \prime} \mathrm{W}\right)$ and Sueste Bay $\left(3^{\circ} 52^{\prime} 1.2^{\prime \prime} \mathrm{S}, 32^{\circ} 25^{\prime} 19.7^{\prime \prime} \mathrm{W}\right)$ which are on the main island (Figure 1; Table 1). The IBAMA authorization to collect algae was registered with the number 050/2006. Seaweed specimens were collected randomly, that is, some individuals in a population were collect without a rule or defined sequence. Whole plants were uprooted and placed in labeled plastic bags. Seaweed samples were frozen and sent to the laboratory where they arrived $48 \mathrm{~h}$ after harvesting. The algae were identified by Prof. Dr. Eurico Cabral de Oliveira Filho. Residual sediment, epiphytes, and animals were removed, and the algae were washed with distilled water to remove seawater and air dried in a circulating air oven at $40^{\circ} \mathrm{C}$ for $48 \mathrm{~h}$. After drying, around $5 \mathrm{~g}$ of each seaweed species was powdered by a triturating process in a grail after freezing the samples with liquid nitrogen. The powdered seaweeds were kept in a freezer until analysis was performed.

2.3. Sample and Calibration Solution Preparation. Samples of $250 \mathrm{mg}$ of each algae species were placed in pyrex test tubes and digested according to a procedure described by Ward et al. [13] . Briefly, $6.0 \mathrm{~mL}$ of nitric acid (65\%) and hydrogen peroxide $(30 \%)$ were added to each test tube and homogenized. Test tubes were then placed on a digestion block overnight ( $c a .12$ hours) and heated at $130 \pm 5^{\circ} \mathrm{C}$ until a translucid, particle-free, and fully digested solution was obtained. $5.00 \mathrm{~mL}$ of ultrapure water were transferred to the digested (sample) solution using a pyrex volumetric
TABLE 1: Classification and sampling for eleven macroalgae studied in Fernando de Noronha archipelago, of northeastern Brazil.

\begin{tabular}{|c|c|}
\hline Divisions and species & Site \\
\hline \multicolumn{2}{|l|}{ Chlorophyta } \\
\hline Caulerpa verticillata (J. Agardh, 1847) & $\mathrm{S}$ \\
\hline \multicolumn{2}{|l|}{ Rhodophyta } \\
\hline $\begin{array}{l}\text { Asparagopsis taxiformis (Delile) Trevisan de } \\
\text { Saint-Léon, } 1845\end{array}$ & S \\
\hline Dictyurus occidentalis (J. Agardh, 1847) & $\mathrm{C}$ \\
\hline $\begin{array}{l}\text { Galaxaura rugosa (J. Ellis \& Solander) J. V. } \\
\text { Lamouroux, } 1816\end{array}$ & $\mathrm{C}$ \\
\hline $\begin{array}{l}\text { Galaxaura obtusata (J. Ellis \& Solander) J. V. } \\
\text { Lamouroux, } 1816\end{array}$ & $\mathrm{C}$ \\
\hline $\begin{array}{l}\text { Galaxaura marginata (J. Ellis \& Solander) J. V. } \\
\text { Lamouroux, } 1816\end{array}$ & $\mathrm{C}$ \\
\hline \multicolumn{2}{|l|}{ Phaeophyta } \\
\hline Dictyota cervicornis (Kützing, 1859) & S \\
\hline Dictyopteris justii (J. V. Lamouroux, 1809) & S \\
\hline Dictyopteris plagiogramma (Montagne) Vickers, 1905 & $\mathrm{C}$ \\
\hline Padina gymnospora (Kützing) Sonder, 1871 & $\mathrm{C}$ \\
\hline Sargassum sp. (C. Agardh, 1820) & $\mathrm{S}$ \\
\hline
\end{tabular}

pipette, and the resulting solution was homogenized. The blank was a mixture of nitric acid, hydrogen peroxide, and deionized water and was done using the same procedure performed to the samples. Then $1.00 \mathrm{~mL}$ of this solution was removed using a pyrex volumetric pipette and to this aliquot was added $10 \mu \mathrm{L}$ of $\mathrm{Ga}\left(1.0 \mu \mathrm{L} \mathrm{mL}^{-1}\right)$ as an internal standard [14]. Calibration solutions of multielements that emit X-K and $\mathrm{X}-\mathrm{L}$ rays were prepared, and Ga element was added as internal standard as above. $5.0 \mu \mathrm{L}$ of each sample were placed on a perspex support (polished quartz, $28 \times 22 \mathrm{~mm}$ ). The same procedure was done for $5.0 \mu \mathrm{L}$ of calibration solution. Drying for $1 \mathrm{~h}$ under, a $150 \mathrm{~W}$ infrared lamp (Phillips model 7, Amsterdam, NH, Netherlands) gave rise to a thin layer of approximately $5 \mathrm{~mm}$ diameter. Sample and calibration solutions were irradiated as described below.

2.4. Instrumentation and Analysis Conditions. The equipment used was an X-ray fluorescence beamline constructed at the National Synchrotron Light LaboratoryLNLS (Campinas, São Paulo State, Brazil). For the total reflection of radiation, a series of mirrors are adjusted to allow that the synchrotron radiation hit the sample in small angle. The sample and calibration solutions were analyzed (three replicates of each) for $100 \mathrm{~s}$ each with a white synchrotron radiation beam using $0.5 \mathrm{~mm}$ of $\mathrm{Al}$ as absorber, $1.0 \mathrm{~mm}$ of $\mathrm{Ta}$ as collimator in the detector, a sample-todetector distance of $1.1 \mathrm{~mm}$, a height of $1 \mathrm{~mm}$ under total reflection conditions, and an angle of incidence of $1 \mathrm{mrad}$. The characteristic X-rays were detected with the aid of a Ge hyperpure semiconductor detector (resolution of $145 \mathrm{eV}$ for energy of $5.9 \mathrm{keV})$. 


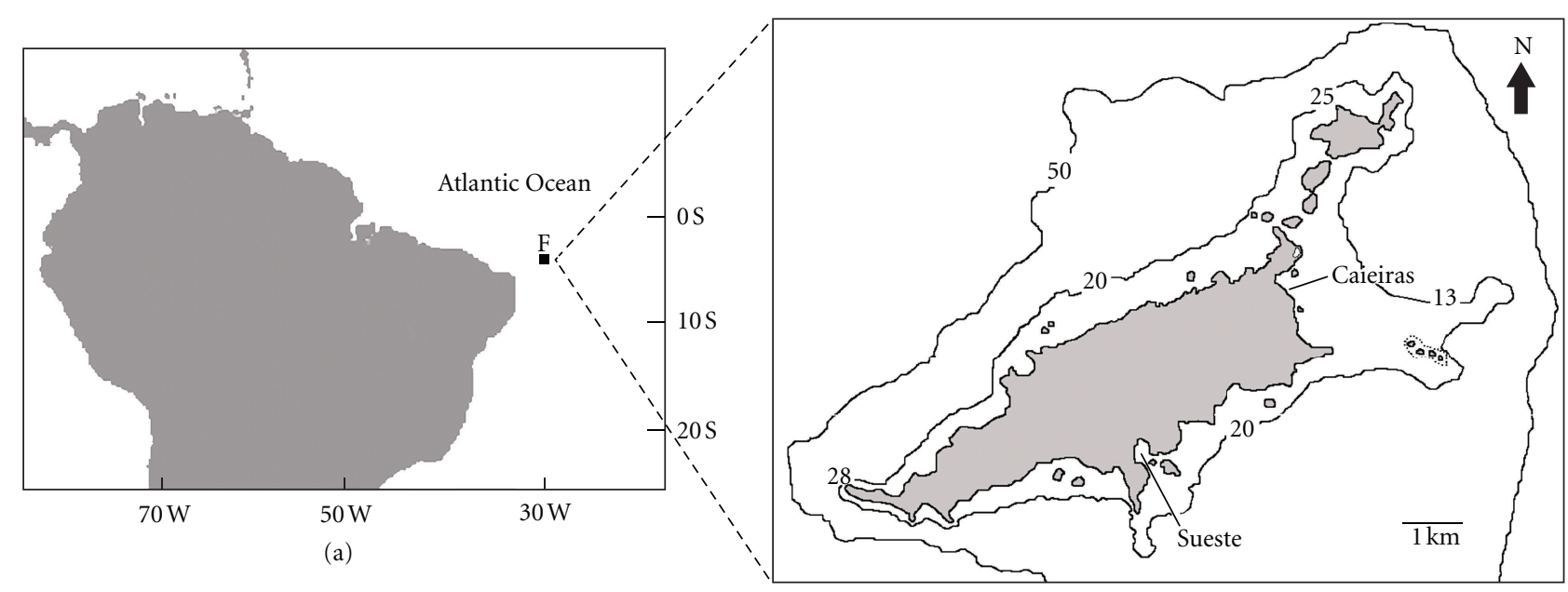

(b)

FIgure 1: Geographical localization of study sites (Caieiras and Sueste) at the main island of Fernando de Noronha archipelago, off northeastern Brazil, where seaweeds were collected.

2.5. Quantitative Analysis for X-Ray Fluorescence. Energy peaks detected in specters of the calibration samples were determined on the spectrometer, and the energy-emitting elements were identified from their X-ray characteristics (analytical lines). The liquid intensities for characteristic Xrays emitted were calculated with a mathematic adjustment in which the contribution of interfering lines on the analytical line (spectral interference) was considered including the escape peak and the addition peak. Mathematical adjustments were calculated with the software AXIL [15].

In quantitative analysis, the fluorescent intensity of the characteristic line is related to the concentration by the expression $I_{i}=S_{i} \times C_{i} \times A_{i}$, where $I_{i}=$ fluorescent intensity of element $i$ (cps), $S_{i}=$ elemental sensitivity of element $i$ $\left(\operatorname{cps} \mu \mathrm{g}^{-1} \mathrm{~mL}\right), C_{i}=$ concentration of element $i\left(\mu \mathrm{g} \mathrm{mL}^{-1}\right)$, and $A=$ absorption factor.

Given the tiny thickness of the prepared samples, the absorption and/or intensification effects (matrix effect) of the analytical line are negligible. Thus, there is no need to consider the absorption factor [16], and the relation is $I_{i}=$ $S_{i} \times C_{i}$.

To correct like geometry and X-ray flow variation errors during excitation, Ga was used as internal standard. Ga is not present in the macroalgae samples. Referencing to internal standard yields the expression $\left(I_{i} / I_{\mathrm{Ga}}\right)=\left(S_{i} / S_{\mathrm{Ga}}\right) \times\left(C_{i} / C_{\mathrm{Ga}}\right)$, where $I_{\mathrm{Ga}}=$ fluorescent intensity of $\mathrm{Ga}$ (cps), $S_{\mathrm{Ga}}=$ elemental sensitivity of $\mathrm{Ga}\left(\mathrm{cps} \mu \mathrm{g}^{-1} \mathrm{~mL}\right)$, and $C_{\mathrm{Ga}}=$ concentration of $\mathrm{Ga}\left(\mu \mathrm{g} \mathrm{mL}^{-1}\right)$.

If we define $S_{i}^{\prime}=S_{i} / S_{\mathrm{Ga}}$ and $R_{i}=C_{\mathrm{Ga}} \times\left(I_{i} / I_{\mathrm{Ga}}\right)$, where $S_{i}^{\prime}=$ relative sensitivity for element $i$ (unidimensional) and $R_{i}=$ product of relative intensity and $C_{\mathrm{Ga}}\left(\mu \mathrm{g} \mathrm{mL}^{-1}\right)$, then

$$
R_{i}=S_{i}^{\prime} \times C_{i}
$$

In the calibration solutions, $R_{i}$ is directly proportional to $C_{i}$; therefore, the angular coefficient of the calibration curve for the element $i$ is its relative sensitivity. If $S_{i}^{\prime}$ is known for the elements present in the calibration solutions, then the following function is obtained:

$$
\ln S_{i}^{\prime}=a+b Z_{i}+c Z_{i}^{2}+d Z_{i}^{3},
$$

where $a, b, c$, and $d$ are parameters that can be determinated by variance analyses, and $Z_{i}$ is the atomic number for element $i$.

The relative sensitivity for any $\mathrm{X}-\mathrm{K}$ or $\mathrm{X}-\mathrm{L}$ ray emitting elements present in the samples can thus be calculated. The SANEST program was used to test significance of the parameters at $5 \%$ probability for inclusion in the model which was used to determine the above (2) [17]. The concentrations $\left(\mu \mathrm{g} \mathrm{mL}^{-1}\right.$ or $\left.\mu \mathrm{gg}^{-1}\right)$ for any inorganic element present in different samples were obtained from (1) after obtaining the experimental limits of detection (LD)(3)

$$
\mathrm{LD}_{i}=\frac{3 \cdot \sqrt{\mathrm{BG}_{i} / t} \cdot C_{\mathrm{Ga}}}{I_{\mathrm{Ga}} \cdot S_{i}^{\prime}},
$$

where $\mathrm{BG}_{i}=$ background (cps), $t=$ detection time (s), and other variables are defined above $[18,19]$.

From the calculation of the experimental LD values, it was established that the values of LD are a polynomial function of the atomic number of the elements present, $\mathrm{LD}_{i}=f\left(Z_{i}\right)$. Thus, using this formula, it is possible to calculate the LD for the elements which are not present in the sample.

\section{Results and Discussion}

Calibration curves $\left(\ln S_{i}^{\prime}=f\left(Z_{i}\right)\right)$ with significant parameters at $5 \%$ level were obtained for all X-K (Table 2, Figure 2) and $\mathrm{X}-\mathrm{L}$ ray (Table 3, Figure 3 ) emitting elements through the multielementary calibration solutions. For the SRTXRF technique, the maximum $S_{i}^{\prime}$ value obtained is for the internal standard which was the element $\mathrm{Ga}(Z=31)$ in this 


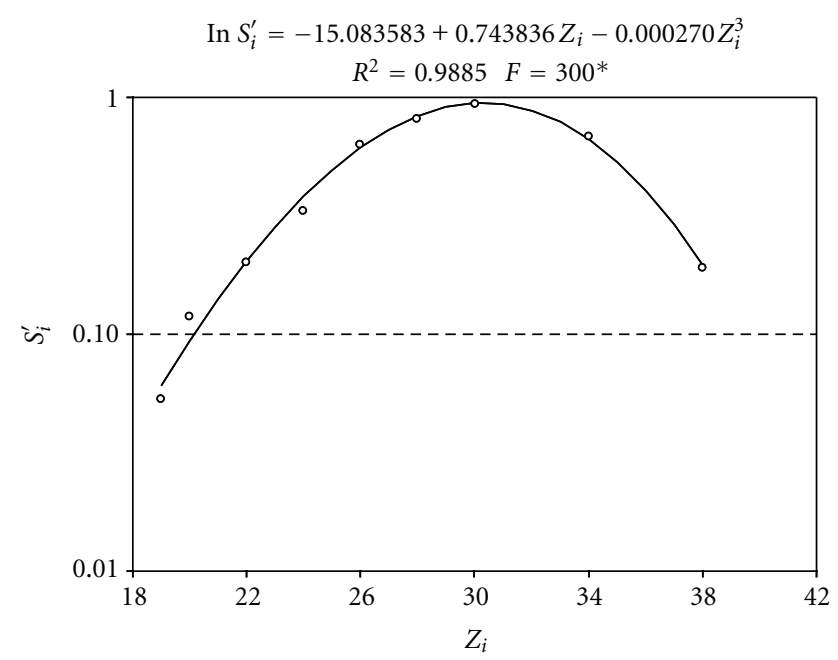

FIgURE 2: Experimental and calculated relative sensitivity for chemical elements emitting X-K rays for $19 \leq Z_{i} \leq 38$.

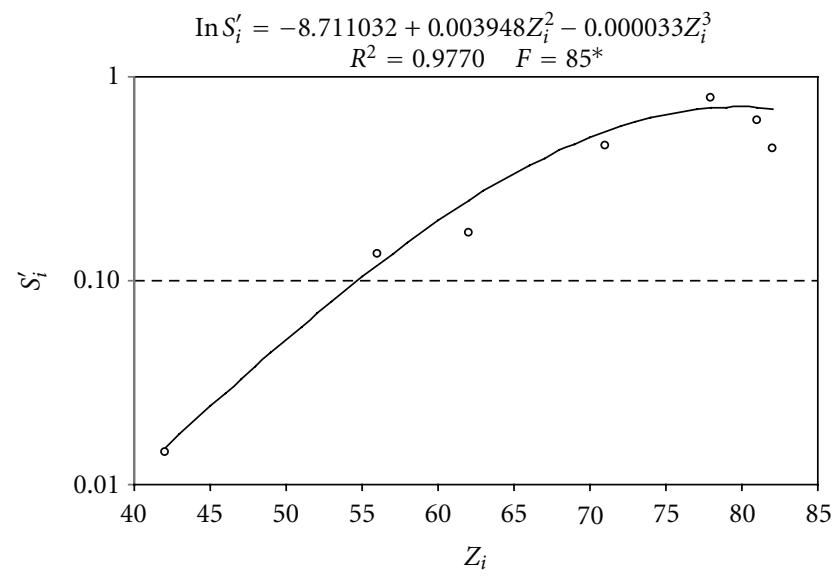

FIgURE 3: Experimental and calculated relative sensitivity for chemical elements emitting X-L rays for $42 \leq Z_{i} \leq 82$.

experiment. The functions increase for $Z<31$ until $Z=31$ and decreasing for $Z>31$. Theoretically, $S_{\mathrm{Ga}}^{\prime}=1.0$; however, the experimental value of $\mathrm{Ga}$ was 0.93 . It is important to correct for this difference in the calculation of the other elements. In this case, if the experimental data were used without experimental correction, an error of $6.6 \%$ can be observed for all the elements. Some authors attribute the need to perform these corrections to obtain the values close to true net intensities [20].

The minimum detection limits for $\mathrm{X}-\mathrm{K}$ and $\mathrm{X}-\mathrm{L}$ ray emitting elements are presented in Table 4. The lowest recorded detection limit for $\mathrm{X}-\mathrm{K}$ ray emitting elements was $\mathrm{LD}=0.01 \mathrm{ppm}$ for $\mathrm{Zn}(Z=30)$ and $\mathrm{Ni}(Z=28)$ and the highest detection limit value was $\mathrm{LD}=1.72 \mathrm{ppm}$ for $\mathrm{K}$ $(Z=19)$. Lowest and highest detection limit values for X$\mathrm{L}$ ray emitting elements were, respectively, $0.01 \mathrm{ppm}$ for $\mathrm{Cu}$ $(Z=29)$ and $1.57 \mathrm{ppm}$ for Mo $(Z=42)$. After determining the experimental detection limits, the concentration of each chemical element was estimated (Table 5). The results of the
TABle 2: Experimental and calculated mean relative sensitivity, $S_{i}^{\prime}$, and mean standard deviation for chemical elements emitting X-K rays for $19 \leq Z_{i} \leq 38$.

\begin{tabular}{lcccc}
\hline Element & $Z_{i}$ & $S_{i}^{\prime}$ (experimental) & $s(m)^{\mathrm{a}}$ & $S_{i}^{\prime}$ (calculated) \\
\hline $\mathrm{K}$ & 19 & 0.053007 & 0.004082 & 0.060650 \\
$\mathrm{Ca}$ & 20 & 0.118720 & 0.006506 & 0.093774 \\
$\mathrm{Ti}$ & 22 & 0.200669 & 0.015206 & 0.203081 \\
$\mathrm{Cr}$ & 24 & 0.329118 & 0.017632 & 0.381365 \\
$\mathrm{Fe}$ & 26 & 0.632468 & 0.027613 & 0.613014 \\
$\mathrm{Ni}$ & 28 & 0.810042 & 0.030792 & 0.832589 \\
$\mathrm{Zn}$ & 30 & 0.930767 & 0.025492 & 0.943175 \\
$\mathrm{Se}$ & 34 & 0.665939 & 0.051780 & 0.666817 \\
$\mathrm{Sr}$ & 38 & 0.190190 & 0.019045 & 0.195293 \\
\hline${ }^{a} s(m)=$ standard deviation $=S_{i}^{\prime}($ exprimental $) / \sqrt{n}, n=9$. \\
\multicolumn{5}{c}{}
\end{tabular}

TABle 3: Experimental and calculated mean relative sensitivity, $S_{i}^{\prime}$, and mean standard deviation for chemical elements emitting X-L rays for $42 \leq Z_{i} \leq 82$.

\begin{tabular}{lcccc}
\hline Element & $Z_{i}$ & $S_{i}^{\prime}$ (experimental) & $s(m)^{\mathrm{a}}$ & $S_{i}^{\prime}$ (calculated) \\
\hline $\mathrm{Mo}$ & 42 & 0.014521 & 0.001182 & 0.015121 \\
$\mathrm{Ba}$ & 56 & 0.135400 & 0.008366 & 0.119381 \\
$\mathrm{Sm}$ & 62 & 0.170940 & 0.007042 & 0.246660 \\
$\mathrm{Lu}$ & 71 & 0.457106 & 0.014518 & 0.537822 \\
$\mathrm{Pt}$ & 78 & 0.789765 & 0.060052 & 0.743550 \\
$\mathrm{Tl}$ & 81 & 0.612795 & 0.047333 & 0.707681 \\
$\mathrm{~Pb}$ & 82 & 0.445363 & 0.012872 & 0.697799 \\
\hline
\end{tabular}

${ }^{a} s(m)=$ standard deviation $=S_{i}^{\prime}($ exprimental $) / \sqrt{n}, n=9$.

analysis of algae (Table 5) and the chemical composition of the alkaline rocks where the algae were collected (Table 6) were compared.

Essential elements $\mathrm{Ca}, \mathrm{Fe}, \mathrm{K}, \mathrm{Mn}$, and $\mathrm{Zn}$ were found in all algae samples as were relevant species $\mathrm{CaO}, \mathrm{Fe}_{2} \mathrm{O}_{3}$, $\mathrm{K}_{2} \mathrm{O}, \mathrm{MnO}$, and $\mathrm{Zn}$ in the rocks upon which these algae grew. Interestingly, G. marginata had little $\mathrm{Fe}(75.27 \mathrm{ppm})$ while $D$. plagiogramma had over 150 times that amount (11936.65 ppm). P. gymnospora (3028.40 ppm) had the least values of $\mathrm{Ca}$ while G. marginata and A. taxiformis had the highest Ca levels detected (82606.32 and $88908.21 \mathrm{ppm}$, resp.). Relatively little $\mathrm{K}$ was found in $C$. verticillata (504.13 ppm) while the levels of $\mathrm{K}$ in $D$. occidentalis were almost 100 times this amount $(49523.34 \mathrm{ppm})$. Also, the $P$. gymnospora had large amounts of $\mathrm{Zn}(274.44 \mathrm{ppm})$ whereas five algae species had levels of $\mathrm{Zn}$ in the range of $2-7 \mathrm{ppm}$ Also, $\mathrm{Sr}$ was found in all rocks analyzed (ca. 950-1750 ppm) and was absorbed by all algae species and in relatively large abundance (ca. 500-6000 ppm). In contrast, Ba was generally abundant in rock samples (ca. 20-1350 ppm) from where the algae were collected, but $\mathrm{Ba}$ was only detected in $D$. justii. While $\mathrm{Br}$ was detected in several species, it was most concentrated in A. taxiformis (257.10 ppm).

The results obtained by SRTXRF analysis of algae are comparable to those obtained for algae from other parts of the world using other analytical methods. For example, 


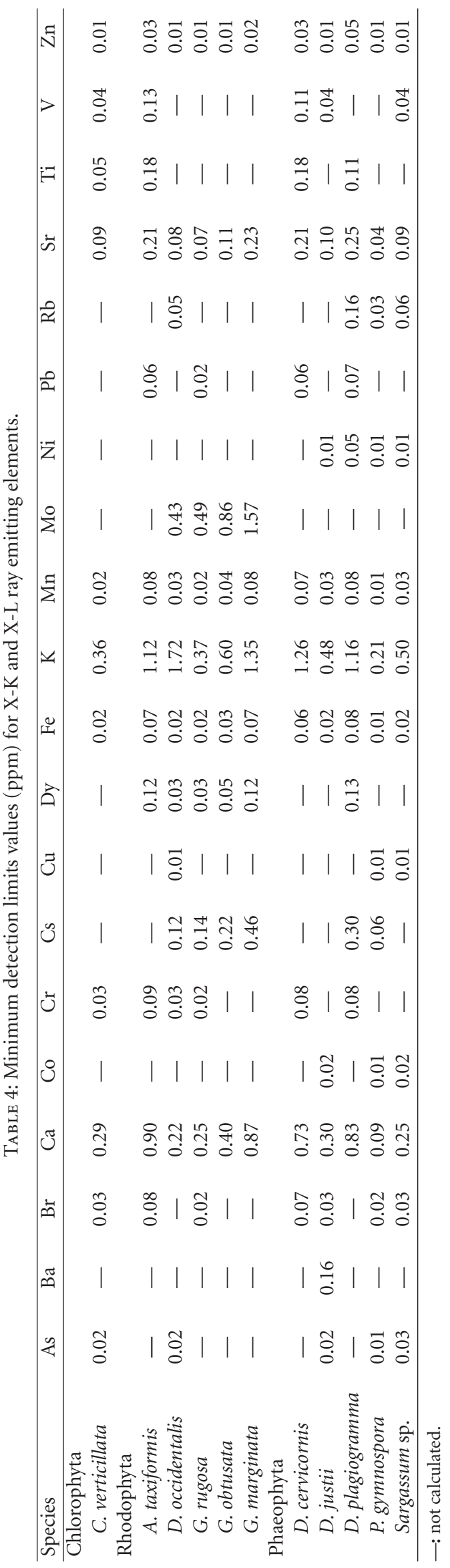




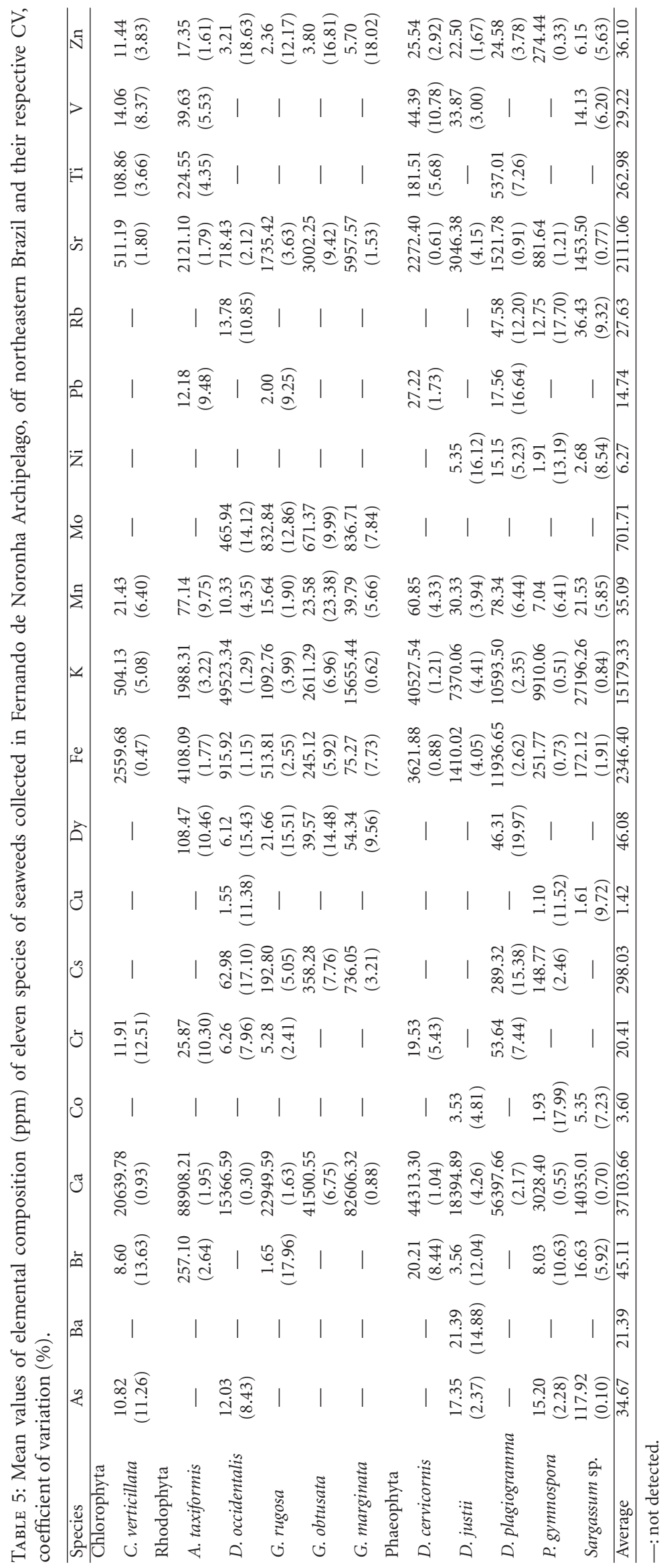


TABLE 6: Representative chemical composition of alkaline rocks from Caieiras ( 1 to 5 ) and Sueste (6 to 8).

\begin{tabular}{|c|c|c|c|c|c|c|c|c|c|}
\hline \multicolumn{5}{|c|}{ Caieiras } & \multicolumn{5}{|c|}{ Sueste } \\
\hline & 1 & 2 & 3 & 4 & 5 & 6 & 7 & 8 & Average \\
\hline $\mathrm{K}_{2} \mathrm{O}^{\mathrm{a}}$ & 1.45 & 4.85 & 4.86 & 2.92 & 1.83 & 2.21 & 5.16 & 3.67 & 3.37 \\
\hline $\mathrm{CaO}^{\mathrm{a}}$ & 11.2 & 5.80 & 4.10 & 6.81 & 12.5 & 10.5 & 0.58 & 5.73 & 7.15 \\
\hline $\mathrm{TiO}_{2}{ }^{\mathrm{a}}$ & 3.19 & 2.36 & 1.18 & 2.40 & 3.86 & 3.37 & 0.17 & 2.26 & 2.35 \\
\hline $\mathrm{MnO}^{\mathrm{a}}$ & 0.18 & 0.18 & 0.15 & 0.21 & 0.16 & 0.21 & 0.19 & 0.12 & 0.18 \\
\hline $\mathrm{Fe}_{2} \mathrm{O}_{3 \text { total }}{ }^{\mathrm{a}}$ & 12.9 & 5.99 & 4.57 & 7.71 & 12.5 & 13.2 & 2.23 & 4.79 & 7.99 \\
\hline $\mathrm{V}^{\mathrm{b}}$ & 275.1 & 164.0 & 71.0 & 171.8 & 239.9 & 257.0 & 13.0 & 187.4 & 172.40 \\
\hline $\mathrm{Cr}^{\mathrm{b}}$ & 505.1 & 229.0 & - & 37.3 & 303.5 & 303.0 & - & - & 275.58 \\
\hline $\mathrm{Co}^{\mathrm{b}}$ & 55.0 & 19.1 & 8.00 & 15.8 & 48.2 & 44.6 & - & 8.77 & 28.50 \\
\hline $\mathrm{Ni}^{\mathrm{b}}$ & 358.9 & 23.6 & 17.9 & 62.4 & 295.5 & 309.6 & - & 19.6 & 155.36 \\
\hline $\mathrm{Cu}^{\mathrm{b}}$ & 53.3 & 7.90 & 4.20 & - & 51.3 & 53.1 & - & - & 33.96 \\
\hline $\mathrm{Zn}^{\mathrm{b}}$ & 57.5 & 97.0 & 95.3 & 94.3 & 122.5 & 114.1 & 181.0 & 80.0 & 105.21 \\
\hline $\mathrm{Rb}^{\mathrm{b}}$ & 53.0 & 142.0 & 142.5 & 80.5 & 47.1 & 49.1 & 322.0 & 96.5 & 116.59 \\
\hline $\mathrm{Sr}^{\mathrm{b}}$ & 960.9 & 820.8 & 1329 & 1620 & 1744 & 1023 & - & 1520 & 1288.24 \\
\hline $\mathrm{Mo}^{\mathrm{b}}$ & 2.14 & - & 7.00 & 6.07 & 2.57 & 2.00 & - & 3.82 & 3.93 \\
\hline $\mathrm{Cs}^{\mathrm{b}}$ & 1.20 & 1.90 & 2.40 & 3.67 & 0.55 & 1.00 & - & 4.33 & 2.15 \\
\hline $\mathrm{Ba}^{\mathrm{b}}$ & 510.2 & 946.0 & 1191 & 1070 & 906.4 & 558.0 & 19.0 & 1330 & 816.33 \\
\hline$D y^{b}$ & 5.96 & 7.10 & 6.60 & 5.94 & 8.11 & 6.90 & - & 6.90 & 6.79 \\
\hline $\mathrm{Pb}^{\mathrm{b}}$ & - & 13.3 & 14.7 & 14.5 & 5.21 & 7.20 & 32.0 & 11.9 & 14.12 \\
\hline
\end{tabular}

—: not detected; ${ }^{\mathrm{a}} \mathrm{wt} \% ;{ }^{\mathrm{b}} \mathrm{ppm}$, —not analyzed . Using the procedure described in Janasi et al. [21], major, minor, and trace elements were determined by inductively coupled plasma-mass spectrometer (ICP-MS).

Hou and Yan [22] studied elements present in 35 species of marine algae from the coast of China by neutron activation analysis in a miniature neutron source reactor (MNSR). They observed that, in brown, red, and green algae, the levels of individual elements were (averages, resp., in parentheses): As $(159 /<0.36 / 12.2 \mathrm{ppm}), \mathrm{Ba}(76.2 / 109.6 / 174 \mathrm{ppm}), \mathrm{Br}(3426 /$ $6157 / 596 \mathrm{ppm}), \mathrm{Ca}(22.7 / 29.7 / 11.2 \mathrm{ppt})$, Co $(0.93 / 1.15 /$ $1.04 \mathrm{ppm}), \quad \mathrm{Cr} \quad(4.02 / 4.84 / 6.33 \mathrm{ppm}), \quad$ Cs $\quad(1.11 / 1.02 /$ $0.95 \mathrm{ppm}), \quad \mathrm{Fe} \quad(1892 / 2511 / 3716 \mathrm{ppm}), \quad \mathrm{K} \quad(67.5 / 48.4 /$ $29.0 \mathrm{ppt}), \mathrm{Mn} \quad(857 / 89.4 / 90.6 \mathrm{ppm}), \mathrm{Rb} \quad(29.4 / 21.5 /$ $25.8 \mathrm{ppm}), \mathrm{Sr}(892 / 313 / 161 \mathrm{ppm})$, and $\mathrm{Zn}(21.7 / 28.3 /$ $23.3 \mathrm{ppm}$ ). Besides this study, in another work about 26 marine benthic algae species found in Karachi Coast, Pakistan, the levels (averages for the 26 species are in parentheses) of $\mathrm{Ca}(26.75 \mathrm{ppt}), \mathrm{Co}(5.88 \mathrm{ppm}), \mathrm{Cr}$ (5.13 ppm), Cu (11.87 ppm), Fe (2.41 ppt), K (69.5 ppt), Pb $(13.43 \mathrm{ppm})$, and $\mathrm{Zn}(53.28 \mathrm{ppm})$ were established using flame atomic absorption spectrometry (AAS) [23]. As in the algae in these previous studies, the algae of Fernando de Noronha were found to contain large amounts of $\mathrm{Ca}$, $\mathrm{K}$, and $\mathrm{Fe}$ (in parts per thousand, ppt) and small or trace amounts of $\mathrm{As}, \mathrm{Ba}, \mathrm{Co}, \mathrm{Cr}, \mathrm{Cs}, \mathrm{Cu}, \mathrm{Pb}, \mathrm{Rb}$, and $\mathrm{Zn}$. Since data on the composition of the surfaces where algae in these previous studies grew was not reported, it is not possible to ascertain the contributions of these surface substrates to the composition of the algae. The similar compositional trends in principle and trace elements present in algae from these previous studies and those of Fernando de Noronha lends support to the usefulness of the SRTXRF technique in the analytical arsenal.
Low numbers of algae species contained $\mathrm{Rb}$ (4 algae species, $12-48 \mathrm{ppm}$ ), Ti (4 species, $109-537 \mathrm{ppm}$ ), and $\mathrm{V}$ (5 species, $14-44 \mathrm{ppm}$ ) which may be related to geological characteristics of the alkaline rocks present in the study sites. Low concentrations of As (5 species, range 11-118 ppm), Co (3 species, 1.9-5.4 ppm), Cr (6 species, range 5.3-54 ppm), $\mathrm{Cu}$ (3 species, range $1.1-1.6 \mathrm{ppm}), \mathrm{Ni}$ (4 species, range $1.9-15 \mathrm{ppm}$ ), and $\mathrm{Pb}$ (4 species, range $2.0-27 \mathrm{ppm}$ ) were observed in most of the algae species, except for Sargassum sp. which had a higher concentration of As (118 ppm) compared to the other species. These elements may have been absorbed from the seawater through natural weathering and lixiviation of rocks and soil.

An interesting finding was the detection of Dy which is a rare earth metal present in rocks of both collection sites in $A$. taxiformis, D. occidentalis, G. rugosa, G. obtusa, G. marginata, and $D$. plagiogramma. Thus, these algae absorb and store this rare chemical element which is present in rocks in relatively low abundance.

\section{Conclusion}

The SRTXRF technique proved to be adequate for the determination of 20 chemical elements present in eleven species of common macroalgae of Fernando de Noronha archipelago providing baseline information for the accumulation of metals in two sites. The results indicate a relationship among the metals present in the seaweeds and the rocks present in this area. Besides, the concentrations of common 
macro- and microelements obtained are comparable to those obtained by other authors using different analytical methods. However, multielement capability in a single analysis, highsensitivity and precision, short analysis time, and easy sample preparation are some advantages of SRTXRF when compared to other elemental determination techniques such as AAS or ICP-MS.

\section{Acknowledgments}

The authors thank the Laboratório Nacional de Luz Síncrotron (LNLS-Campinas, SP) for allowing the use of beam line facilities and for CNPq, FAPESP, and CAPES for financial support. The authors declare that they do not have any conflict of interests.

\section{References}

[1] U. G. Cordani, M. N. Ulbrich, E. A. Menor, and R. P. Lopes, "Cenozoic alkaline volcanism of Fernando de Noronha island," in South American Symposium on Isotope Geology, Field Trip Guide, pp. 1-24, CBPM/IRD, Salvador, 2003.

[2] G. Dickie, "Enumeration of algae collected at Fernando de Noronha by H. M. Moseley, N. A. naturalist to H. M. S. "Challenger"," Journal Linnean Society, vol. 14, pp. 363-365, 1874.

[3] F. Pinheiro-Vieira and M. M. Ferreira-Correia, "Quarta contribuição ao inventário das algas marinhas bentônicas do nordeste brasileiro," Arquivos de Ciências do Mar, vol. 10, pp. 189-192, 1970.

[4] E. C. de Oliveira Filho, "An annotated list of the Brazilian seaweeds in Dickie's herbarium," Botanical Journal of the Linnean Society, vol. 69, no. 3, pp. 229-238, 1974.

[5] Pedrini A. G., Y. Ugadim, M. R. A. Braga, and S. M. B. Pereira, "Algas marinhas bentônicas do Arquipélago de Fernando de Noronha, Brasil," Boletim de Botânica da USP, vol. 13, pp. 93101, 1992.

[6] V. R. Eston, A. E. Migotto, E. C. O. Filho, S. A. Rodrigues, and J. C. Freitas, "Vertical distribution of benthic marine organisms on rocky coasts of the Fernando de Noronha Archipelago (Brazil)," Boletim do Instituto Oceanográfico de São Paulo, vol. 34, pp. 37-53, 1986.

[7] C. S. Lobban and P. J. Harrison, Seaweed Ecology and Physiology, Cambridge University, Cambridge, UK, 1997.

[8] G. M. Amado-Filho, L. T. Salgado, M. F. Rebelo, C. E. Rezende, C. S. Karez, and W. C. Pfeiffer, "Heavy metals in benthic organisms from Todos os Santos Bay, Brazil," Brazilian Journal of Biology, vol. 68, no. 1, pp. 95-100, 2008.

[9] G. W. Bryan, "The effects of heavy metals (other than mercury) on marine and estuarine organisms," Proceedings of the Royal Society of London. Series B, vol. 177, no. 48, pp. 389410, 1971.

[10] G. W. Bryan and L. G. Hummerstone, "Indicators of heavy metal contamination in the Looe Estuary (Cornwall) with particular regard to silver and lead," Journal of the Marine Biological Association of the United Kingdom, vol. 57, pp. 7592, 1977.

[11] Y. Serfor-Armah, B. J. B. Nyarko, E. K. Osae, D. Carboo, S. Anim-Sampong, and F. Seku, "Rhodophyta seaweed species as bioindicators for monitoring toxic element pollutants in the marine ecosystem of Ghana," Water, Air, and Soil Pollution, vol. 127, no. 1-4, pp. 243-253, 2001.
[12] M. Rajfur, A. Kłos, and M. Wacławek, "Sorption properties of algae Spirogyra sp. and their use for determination of heavy metal ions concentrations in surface water," Bioelectrochemistry, vol. 80, no. 1, pp. 81-86, 2010.

[13] A. F. Ward, L. F. Marciello, L. Carrara, and V. J. Luciano, "Simultaneous determination of major, minor and trace elements in agricultural and biological samples by inductively coupled argon plasma spectrometry," Spectroscopy Letters, vol. 13, pp. 803-831, 1980.

[14] O. L. A. D. Zucchi, S. Moreira, M. J. Salvador, and L. L. Santos, "Multielement analysis of soft drinks by x-ray fluorescence spectrometry," Journal of Agricultural and Food Chemistry, vol. 53, no. 20, pp. 7863-7869, 2005.

[15] P. van Espen, H. Nullens, and F. Adams, "A computer analysis of X-ray fluorescence spectra," Nuclear Instruments and Methods, vol. 142, no. 1-2, pp. 243-250, 1977.

[16] R. Klockenkämper and A. von bohlen, "Determination of the critical thickness and the sensitivity for thin-film analysis by total reflection X-ray fluorescence spectrometry," Spectrochimica Acta Part B, vol. 44, no. 5, pp. 461-469, 1989.

[17] E. P. Zonta and A. Machado, SANEST: Sistema de Análise Estatística para Microcomputadores, CIAGRI-ESALQ-USP, São Paulo, Brazil, 1993.

[18] L. A. Currie, "Limits for qualitative detection and quantitative determination: application to radiochemistry," Analytical Chemistry, vol. 40, no. 3, pp. 586-593, 1968.

[19] W. Ladisich, R. Rieder, P. Wobrauschek, and H. Aiginger, "Total reflection X-ray fluorescence analysis with monoenergetic excitation and full spectrum excitation using rotating anode X-ray tubes," Nuclear Instruments and Methods in Physics Research, vol. 330, no. 3, pp. 501-506, 1993.

[20] M. J. Salvador, D. A. Dias, S. Moreira, and O. L. A. D. Zucchi, "Analysis of medicinal plants and crude extracts by synchrotron radiation total reflection X-ray fluorescence," Journal of Trace and Microprobe Techniques, vol. 21, no. 2, pp. 377-388, 2003.

[21] V. A. Janasi, S. Andrade, and H. H. G. J. Ulbrich, "A correção do drift instrumental em ICP-AES com espectrômetro seqüencial e a análise de elementos maiores, menores e traços em rochas," Boletim do Instituto de Geociências da USP: Série Científica, vol. 26, pp. 45-58, 1995.

[22] X. Hou and X. Yan, "Study on the concentration and seasonal variation of inorganic elements in 35 species of marine algae," Science of the Total Environment, vol. 222, no. 3, pp. 141-156, 1998.

[23] M. A. Rizvi and M. Shameel, "Pharmaceutical biology of seaweeds from the Karachi coast of Pakistan," Pharmaceutical Biology, vol. 43, no. 2, pp. 97-107, 2005. 


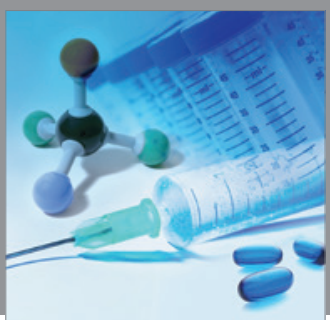

International Journal of

Medicinal Chemistry

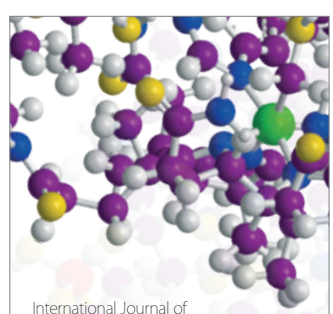

Carbohydrate Chemistry

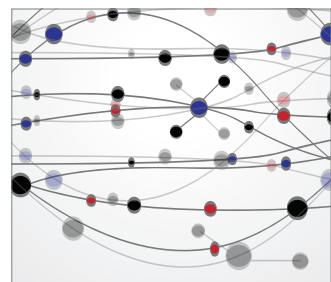

The Scientific World Journal
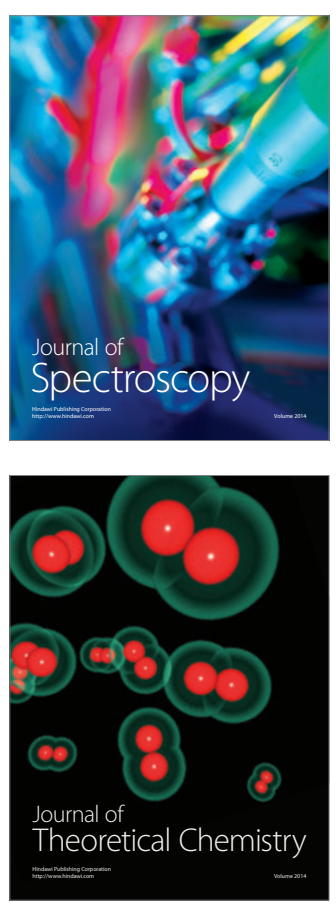
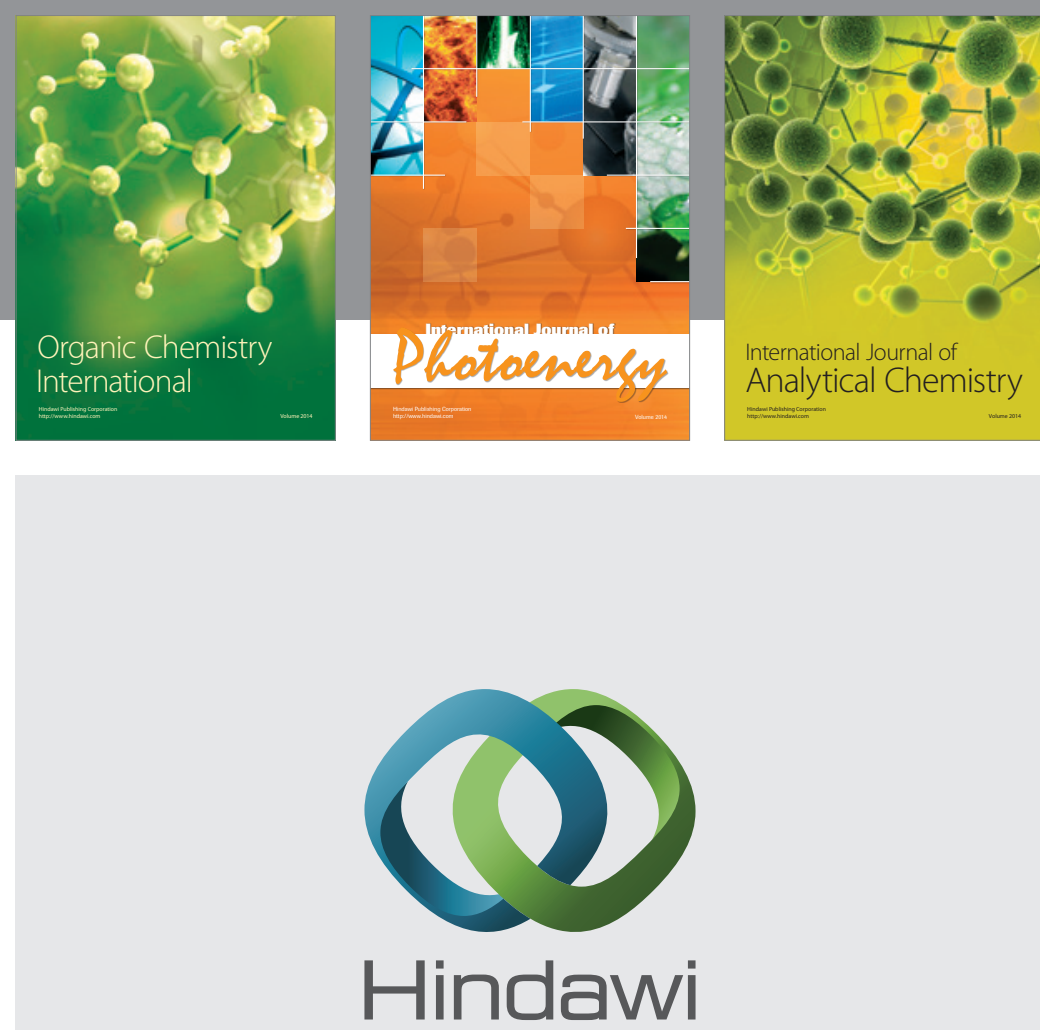

Submit your manuscripts at

http://www.hindawi.com
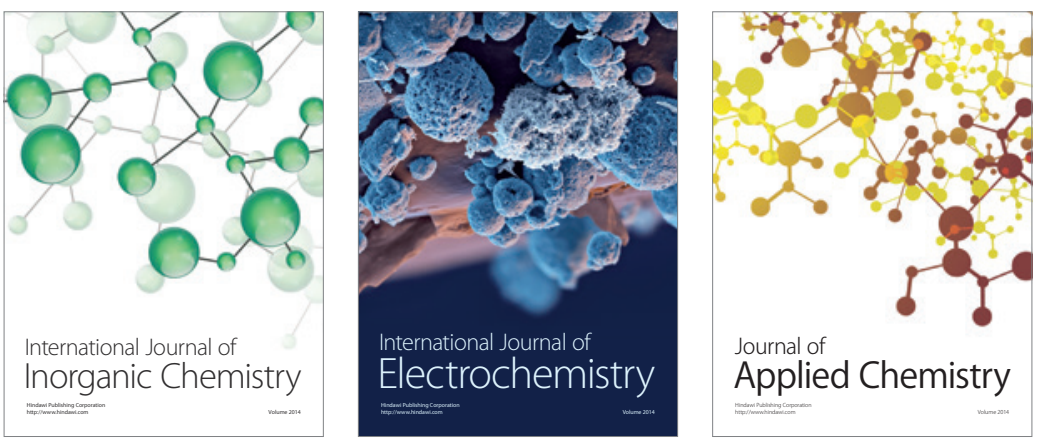

Journal of

Applied Chemistry
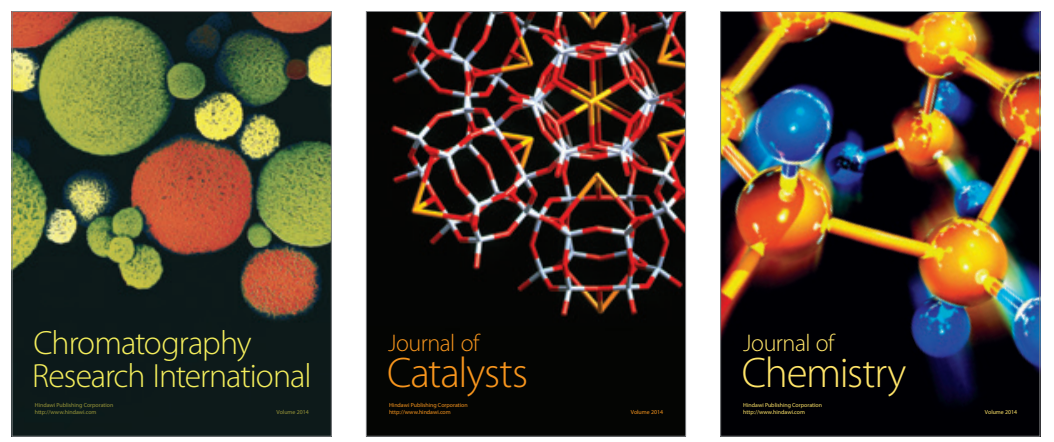
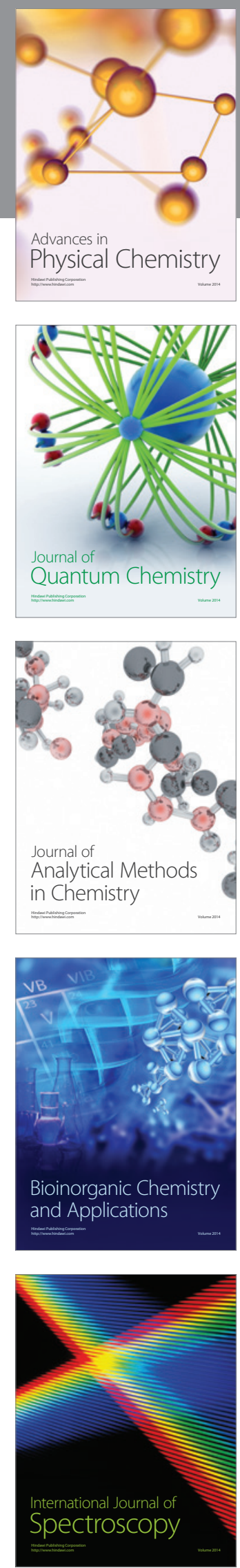